\title{
Resistensi Antibakteri pada Pasien Infeksi Saluran Kemih (ISK) dengan Kateterisasi Urin di Bagian Penyakit Dalam RSUD Arifin Achmad Pekanbaru
}

\author{
Taswin Yacob $^{1}$, Rita Endriani ${ }^{2}$, M. Yulis Hamidy ${ }^{3}$ M.Arif Budiman ${ }^{4}$
}

\begin{abstract}
Uninary tract infection (UTI) is a common health problem among the people in the world, including Indonesia. Approximately $80 \%$ of UTI in hospital are ascociated with urethral catheter used in hospitalized patients. The increase of catheter- related UTI is olso followed by increase of antibiotic used. The diffrence in distribution of UTI causing bacteria and antibiotics resistance associated with cathetetization can change according to time and place. This stdy aims to find the pattern of antibiotic resistance in the urine of catheter related UTI patient. The research was done in Departement of Internal Medicine RSUD arifin Achmad Pekanbaru. 31 samples were collected from hospitalized patient who used catheter at last 3 days and taken with indwelling catheter urine. Culture, colony count, colony identification and resistance test was performed by Kirby Bauer method. The result was interpretated based on Clinical and Laboratory Standard Institude (CLSI). UTI found in 19 samples (61.29\%), 9 samples founs no bacteria (29.03\%) and Candida albicans on 3 samples (9.68\%). UTI caused mostly by Gram-negative bacteria (57.89\%), Gram- positive bacteria found in $42.11 \%$ of samples. The highest resistance (100\%) was found on cefotaxim, cefriaxon, cefalexin and tertracyclin. The lowest resistance $(73.68 \%)$ found on merofenem and co-trimoxazole.
\end{abstract}

Keywords : Resistance, Antibiotics, catheter - UTI

\section{PENDAHULUAN}

Infeksi saluran kemih (ISK) merupakan masalah kesehatan umum yang dialami oleh jutaan orang tiap tahunnya termasuk di Indonesia. ${ }^{1}$ Berdasarkan data survey Consensus on Nosocomial Urinary Tract Infection (NUTI) in adult patien tahun 2003 terdapat 36,3\%-42,7\% dari infeksi di rumah sakit (hospital acquired infection) merupakan ISK dan $80 \%$ infeksi tersebut dihubungkan dengan pemakaian kateter uretra (indwelling urinary catheter). Infeksi saluran kemih tersebut dikenal sebagai ISK terkait kateter (catheter associated urinary tract infection) ${ }^{2,3}$

Kateterisasi adalah memasukan kateter ke dalam buli-buli melalui uretra dengan tujuan untuk diagnosis dan terapi pasien. Pasien rawat inap rentan mengalami ISK terkait kateter. Sekitar 12-60\% pasien tersebut mendapatkan pemasangan kateter

\footnotetext{
${ }^{1}$ Bagian Syaraf RSUD Arifin Achmad,

${ }^{2}$ Bagian Mikrobiologi FK UR,

${ }^{3}$ Bagian Farmakologi FK UR,

${ }^{4}$ Mahasiswa FK UR
}

uretra selama masa rawatannya di rumah sakit yang akan meningkatkan risiko kejadian ISK sebesar 3$5 \%$ setiap harinya. ${ }^{4,5}$

Tindakan dan perawatan yang optimal serta sistem drainase tertutup sangat diperlukan tetapi ISK atas pada pasien dengan indwelling kateter mengalami peningkatan perhari yaitu sebesar $50 \%$ setelah 4-5 hari, $75 \%$ setelah 7-9 hari, dan $100 \%$ setelah 2 minggu. ${ }^{5}$ Walaupun telah dilakukan cara pemasangan kateter yang sempurna, infeksi masih saja terjadi sebesar $2 \%$ pada kateterisasi tunggal, $10 \%$ pada kateterisasi berulang dan $95 \%-100 \%$ pada kateterisasi menetap. ${ }^{6,7}$

Peningkatan kasus ISK terkait kateter juga diikuti dengan peningkatan pemakaian antibakteri untuk mengatasi infeksi tersebut. Pengobatan ISK dengan menggunakan antibakteri yang sesuai dan rasional dapat menekan biaya pengobatan, mencegah komplikasi lanjutan dari infeksi saluran kemih, dan mencegah resistensi terhadap berbagai antibakteria. $^{8}$ 
Pemakain antibakteri â laktam terutama sefalosporin berspektrum luas sebagai antibakteri lini pertama untuk mengatasi ISK akan berdampak pada munculnya resistensi antibakteri golongan â laktam pada bakteri penyebab ISK terutama bakteri batang Gram negatif ${ }^{8}$.

Penelitian Samirah dkk menunjukan Psudomonas aeruginosa telah resisten terhadap ceftriaxone, amoxicillin-klavulanic acid, nitrofurantion, ampicilin, nalidixic acid dan cefadroxil. ${ }^{9}$ Penelitian Widayati dkk menunjukkan bahwa Proteus resisten terhadap amoksisilin. Enterobacter resisten terhadap ampisilin, Staphylococcus aureus dan Pseudomonas sp resisten terhadap ceftriaxon, sedangkan Enterobacter sensitif terhadap ceftriaxon. ${ }^{10}$

European Epic Study di ICU mencatat bahwa isolat $S$. aureus sebesar 60\% merupakan Methicillin Resistant Staphylococcus aureus (MRSA) dan P.aeruginosa resisten terhadap gentamicin (46\%), imipenem (21\%), ceftazidime (27\%), ciprofloxacin (26\%), dan ureidopenicillin (37\%). ${ }^{11}$

Berdasarkan uraian di atas dapat dilihat betapa pentingnya untuk mengetahui resistensi antibakteri pada pasien ISK dengan kateterisasi urin sebagai di RSUD Arifin Achmad Pekanbaru sehingga dapat digunakan sebagai acuan dalam pemilihan obat selanjutnya.

\section{METODE PENELITIAN}

Penelitian ini merupakan penelitian deskriptif eksperimental laboratorik prospektif yang dilakukan di Bagian Penyakit Dalam RSUD Arifin Achmad dan penelitian adalah pasien rawat inap yang telah menggunakan kateter selama minimal 3 hari di Bagian Penyakit Dalam RSUD Arifin Achmad Pekanbaru. Sampel penelitian adalah urin pasien yang keluar melalui kateter dan diambil dengan Indwelling catheter urine. Selanjutnya dilakukan kultur, hitung koloni, identifikasi koloni dan uji resistensi antibakteri dengan metode Kirby Bauer. Interpretasi hasil sensitif atau resisten mengacu pada buku Clinical and Laboratory Standard Institute (CLSI). ${ }^{12}$

\section{Hasil Penelitian dan Pembahasan}

Berdasarkan kultur dan hitung koloni maka distribusi sampel dan frekuensi ISK di Bagian Penyakit Dalam RSUD Arifin Achmad Pekanbaru. dapat dilihat pada tabel di bawah ini:

Tabel 1. Distribusi dan frekuensi ISK

\begin{tabular}{|c|c|c|}
\hline Diagnosis & $\begin{array}{c}\text { Jumlah Sampel } \\
\text { Penelitian }\end{array}$ & $\%$ \\
\hline Pertumbuhan bakteri bermakna/ISK & 19 & 61,29 \\
\hline Pertumbuhan bakteri tidak bermakna/ Non ISK & 0 & 0 \\
\hline Tidak ada pertumbuhan bakteri & 9 & 29,03 \\
\hline Candida albicans & 3 & 9,68 \\
\hline Total & 31 & 100 \\
\hline
\end{tabular}

Berdasarkan tabel di atas dapat dilihat bahwa sampel lebih banyak terdiagnosis ISK. Hal ini karena kateterisasi urin pada pasien rawat inap merupakan faktor resiko terjadinya ISK. Sekitar $12-60 \%$ pasien rawat inap yang mendapatkan pemasangan kateter urin selama masa rawatannya di rumah sakit akan meningkatkan resiko kejadian ISK sebesar 3-5\% setiap harinya. Hal ini sesuai dengan penelitian Stamm WE (2000) bahwa ISK dijumpai pada paling sedikit $10-15 \%$ pasien rawat inap dengan kateter uretra yang terus terpasang. Kejadian ini terus meningkat sebesar 40-45\%., 4,7,13

Pada penelitian ini ditemukannya Candida $s p$ dalam urin pasien ISK terkait kateter ( Candiduria) yang kemungkinan disebabkan oleh pemakaian antibakteri sistemik dalam jangka waktu lama sehingga menyebabkan gangguan keseimbangan flora di lingkungan periuretra. Selain itu keberadaan Candiduria ini dapat menyebabkan infeksi lanjutan ${ }^{1,6}$. 
Setelah dilakukan identifikasi terhadap hasil kultur dari urin pasien dengan kateter di
Laboratorium Mikrobiologi maka pola bakteri penyebab ISK dapat dilihat pada Tabel 2. di bawah ini:

Tabel .2. Pola Bakteri Penyebab ISK dengan Kateter

\begin{tabular}{lcc}
\hline \multicolumn{1}{c}{ Jenis bakteri } & Jumlah & $\mathbf{\%}$ \\
\hline GRAMPOSITIF & & \\
Staphlococcus saprofitik & 2 & 10,53 \\
Staphylococcusepidermicis & 3 & 15,79 \\
Staphlococcus aureus. & 1 & 5,26 \\
Streptococcus sp & 2 & 10,53 \\
JUMLAH & $\mathbf{8}$ & $\mathbf{4 2 , 1 1}$ \\
\hline GRAM NEGATIF & & \\
Escherichia coli & 4 & 21,05 \\
Enterobacter sp. & 4 & 21,05 \\
Klebsiella sp. & 1 & 5,26 \\
Pseudomonas sp. & 2 & 10,53 \\
JUMLAH & $\mathbf{1 1}$ & $\mathbf{5 7 , 8 9}$ \\
\hline TOTAL & $\mathbf{1 9}$ & $\mathbf{1 0 0} \%$ \\
\hline
\end{tabular}

Berdasarkan tabel di atas dapat dilihat penyebab ISK yang berhubungan dengan kateter urin paling banyak disebabkan oleh bakteri Gram negatif. Hal ini karena ISK pada pasien yang berhubungan dengan kateter ini sering disebabkan oleh bakteri yang hidup di lingkungan lembab di rumah sakit terutama Gram negatif ${ }^{14}$. Pada penelitian ini bakteri Gram negatif penyebab ISK yang paling banyak disebabkan oleh $E$. coli dan Enterobacter sp. Bakteri Gram positif hanya didominasi oleh $S$. epidermidis. . Menurut Mims (2008), penyebab ISK nosokomial terbanyak disebabkan oleh bakteri Gram negatif berupa $E$. coli (40\%) dan Gram negatif lain seperti Enterobacter $s p$ sebanyak $(25 \%)$. Selain itu menurut Wilson bakteri Gram positif kurang berperan dalam ISK, kecuali Staphylococcus $s p^{15}$. Penelitian Sjahrurachman dkk, terhadap pasien yang dirawat inap di RS MMC Jakarta didapatkan bakteri yang dominan penyebab ISK adalah Gram negatif berupa E. coli (36,3\%), diikuti oleh Klebsiella $(19,9 \%)$ dan Pseudomonas $(13,3 \%)^{16}$. Penelitian Husada dkk pada pasien dengan kateterisasi urin ditemukan bakteri yang paling banyak yaitu E.coli sebesar $22 \%$. 17
Bakteri Gram negatif terutama E. coli Uropatogenik (Uropathogenic E. coli/UPEC) merupakan bakteri terbanyak yang menyebabkan ISK termasuk ISK dengan kateterisasi. Hal ini disebabkan karena bakteri ini memiliki fimbriae/ pili yang memudahkan perlekatan dengan uroepitelium saluran kemih dan juga merupakan bakteri opportunistik yang mudah menimbulkan penyakit pada penderita dengan sistem imun yang menurun. $U P E C$ juga dapat menyebabkan nefropatogenik yang secara khas menghasilkan hemolisin dan urease ${ }^{1,6}$. Bakteri Gram positif yang banyak ditemukan pada penelitian ini kemungkinan besar merupakan bakteri yang menyebar melalui darah (bakteriemia) dari infeksi di tempat lain di tubuh atau infeksi lanjutan (super-imfosed infection) 1,6 .

Berdasarkan hasil uji resistensi antibakteri terhadap bakteri penyebab ISK yang terkait kateter didapatkan bahwa seluruh isolat bakteri memiliki resistensi yang tinggi terhadap semua antibakteri yang diujikan. Untuk lebih jelasnya dapat dilihat pada Tabel 3 dan 4 berikut ini. 
Tabel 3. Pola Resistensi Seluruh Isolat Bakteri terhadap Antibakteri

\begin{tabular}{|c|c|c|c|c|c|c|}
\hline \multirow[t]{2}{*}{ No } & \multirow[t]{2}{*}{ Antimila oba } & \multirow[t]{2}{*}{$\mathrm{N}$} & \multicolumn{4}{|c|}{ Hasil } \\
\hline & & & Sensitif & $\%$ & Resisten & $\%$ \\
\hline 1 & Ampicillin (AMP) & 19 & 1 & 5,26 & 18 & 94,74 \\
\hline 2 & $\begin{array}{l}\text { Amoxicillin-clavul anicacid } \\
\text { (AMC) }\end{array}$ & 19 & 4 & 21,05 & 15 & 78,95 \\
\hline 3 & Cephalothin (KF) & 19 & 1 & 5,26 & 18 & 94,74 \\
\hline 4 & Cefotaxim (CTX) & 19 & 0 & 0 & 19 & 100 \\
\hline 5 & Cefriaxon (CRO) & 19 & 0 & 0 & 18 & 100 \\
\hline 6 & Cefuroxim (CXM) & 19 & 1 & 5,26 & 18 & 94,74 \\
\hline 7 & Cefalexin (CL) & 19 & 0 & 0 & 19 & 100 \\
\hline 8 & Merofenem (MEM) & 19 & 5 & 26,32 & 14 & 73,68 \\
\hline 9 & Tetracyclin (TE) & 19 & 0 & 0 & 19 & 100 \\
\hline 10 & Cirofloxacin (CIP) & 19 & 3 & 15,79 & 16 & 84,21 \\
\hline 11 & Ofloxacin (OFX) & 19 & 4 & 21,05 & 15 & 78,95 \\
\hline 12 & Nadilic Acid (NA) & 19 & 1 & 5,26 & 18 & 94,74 \\
\hline 13 & Nitrofurantoin (F) & 19 & 3 & 15,79 & 16 & 84,21 \\
\hline 14 & $\begin{array}{l}\text { Trimetoprimsul fametoxazol } \\
\text { (SXT) }\end{array}$ & 19 & 5 & 26,32 & 14 & 73,68 \\
\hline
\end{tabular}

Berdasarkan Tabel 3 di atas dapat dilihat bahwa sudah terjadi multiresisten antibakteri pada pasien ISK dengan kateterisasi urin ini karena sebagian besar dari antibakteri yang diujikan sudah resisten. Resistensi tertinggi ditemukan pada cefotaxim, cefriaxon, cefalexin dan tetracyclin yaitu $100 \%$. Selain itu resistensi yang terendah ditemukan pada merofenem dan trimetoprimsulfametoxazol yaitu $73,68 \%$. Muratani $\mathrm{T}$ et al juga menemukan tingkat resistensi tetrasiklin yang tinggi pada isolat bakteri penyebab ISK.
Tingginya angka resistensi pada antibakteri golongan sefalosforin berspektrum luas ini kemungkinan disebabkan karena antibakteri ini merupakan antibakteri lini pertama untuk mengatasi kasus ISK terkait kateter ${ }^{12,18}$.Resistensi yang tinggi pada tetrasiklin disebabkan karena tetrasiklin merupakan antibakteri alternatif untuk mengatasi ISK terutama yang disebabkan oleh P.aeruginosa. Resistensi tetrasiklin ini timbul akibat adanya paparan antibakteri yang tidak optimal sehingga bakteri menjadi resisten ${ }^{1}$.

Tabel 4. Pola Resistensi Seluruh Isolat Bakteri Penyebab ISK

\begin{tabular}{|c|c|c|c|c|c|c|c|c|c|}
\hline \multirow[t]{2}{*}{ No } & \multirow[t]{2}{*}{ Antibakteri } & \multicolumn{8}{|c|}{ Frekuen si $(\%)$} \\
\hline & & $\begin{array}{c}\text { Strept } \\
o \\
\mathrm{n}=2\end{array}$ & $\begin{array}{c}\text { S.cureu } \\
s \\
\mathbf{n}=1\end{array}$ & $\begin{array}{c}S . \\
s a p r \\
\mathrm{n}=2\end{array}$ & $\begin{array}{c}\text { S.epid } \\
\mathrm{n}=3\end{array}$ & $\begin{array}{l}\text { Ecoli } \\
\mathrm{n}=4\end{array}$ & $\begin{array}{l}\text { Enter } \\
o \\
\mathrm{n}=4\end{array}$ & $\begin{array}{l}\text { Kleb } \\
s \\
\mathrm{n}=1\end{array}$ & $\begin{array}{l}P_{\text {Send }} \\
o \\
n=2\end{array}$ \\
\hline 1 & $\begin{array}{l}\text { Ampicillin } \\
\text { (AMP) }\end{array}$ & 50 & 100 & 100 & 100 & 100 & 100 & 100 & 100 \\
\hline 2 & $\begin{array}{l}\text { Amoxicillin } \\
\text { - } \\
\text { d avulanicac } \\
\text { id (AMC) }\end{array}$ & 50 & 100 & 100 & 100 & 50 & 100 & 100 & 100 \\
\hline 3 & $\begin{array}{l}\text { Cephal othin } \\
\text { (KF) }\end{array}$ & 100 & 0 & 100 & 100 & 100 & 100 & 100 & 100 \\
\hline 4 & $\begin{array}{l}\text { Cefotaxim } \\
\text { (CTX) }\end{array}$ & 100 & 100 & 100 & 100 & 100 & 100 & 100 & 100 \\
\hline
\end{tabular}




\begin{tabular}{|c|c|c|c|c|c|c|c|c|}
\hline $\begin{array}{l}\text { Cefriaxon } \\
\text { (CRO) }\end{array}$ & 100 & 100 & 100 & 100 & 100 & 100 & 100 & 100 \\
\hline $\begin{array}{l}\text { Cefuroxim } \\
\text { (CXM) }\end{array}$ & 100 & 100 & 100 & 100 & 75 & 100 & 100 & 100 \\
\hline $\begin{array}{l}\text { Cefal exin } \\
\text { (CL) }\end{array}$ & 100 & 100 & 100 & 100 & 100 & 100 & 100 & 100 \\
\hline $\begin{array}{l}\text { Merofenem } \\
\text { (MEM) }\end{array}$ & 100 & 0 & 100 & 100 & 50 & 75 & 50 & 100 \\
\hline $\begin{array}{l}\text { Tetracyclin } \\
\text { (TE) }\end{array}$ & 100 & 100 & 100 & 100 & 100 & 100 & 100 & 100 \\
\hline $\begin{array}{l}\text { Cirofloxacin } \\
\text { (CIP) }\end{array}$ & 100 & 100 & 100 & 100 & 75 & 100 & 100 & 100 \\
\hline $\begin{array}{l}\text { Ofloxacin } \\
\text { (OFX) }\end{array}$ & 100 & 100 & 100 & 100 & 75 & 50 & 100 & 50 \\
\hline $\begin{array}{l}\text { Nadilic } \\
\text { Acid (NA) }\end{array}$ & 100 & 100 & 100 & 100 & 75 & 100 & 100 & 100 \\
\hline $\begin{array}{l}\text { Nitrofuranto } \\
\mathrm{n}(\mathrm{F})\end{array}$ & 0 & 100 & 100 & 100 & 75 & 100 & 100 & 100 \\
\hline $\begin{array}{l}\text { Trimetopri } \\
\text { m } \\
\text { sulfametoxa } \\
\text { zol (SXT) }\end{array}$ & 100 & 100 & 100 & 100 & 75 & 50 & 100 & 0 \\
\hline
\end{tabular}

Berdasarkan Tabel 4 di atas dapat dilihat bahwa resistensi sudah terjadi pada semua jenis bakteri terhadap berbagai antibakteri yang diujikan. Tingginya angka resistensi juga dilaporkan Taher M bahwa ceftriaxon dan cefotaxim telah mengalami resistensi $100 \%$ pada Pseudomonas sp, $71 \%$ pada E.coli, dan $92 \%$ pada Klebsiella. Golongan carbapenem yaitu imipenem resisten terhadap Pseudomonas sp sebesar 25\%. Cifrofloxacin resisten terhadap Pseudomonas (50\%), Klebsiella (70\%), E.coli (43\%), dan Enterobacter sp (25\%). ${ }^{19}$ Penelitian yang dilakukan oleh Dwiprahasto I ditemukan bahwa resistensi yang terjadi pada P.aeruginosa dilaporkan bersifat multipel, termasuk terhadap gentamicin $(46 \%)$, imipenem $(21 \%)$, ceftazidime (27\%), ciprofloxacin (26\%), dan areidopenicillin (37\%), selain itu pada Klebsiella pneumonia dan Enterobacter sp juga resisten terhadap cephalosporin generisasi ketiga, aminoglikosida dan ciprofloxacin. ${ }^{11}$ Endriani R dkk melaporkan resistensi antibakteri terhadap bakteri penyebab ISK pada urin midstream yaitu amoxilinclavulanat mengalami resistensi $71,43 \%$ terhadap E.coli dan $83,33 \%$ terhadap Klebsiella. Cefuroxim resisten $100 \%$ terhadap Klebsiella dan
Pseudomonas. Cefalexin resisten $100 \%$ terhadap Klebsiella, Pseudomonas, Proteus. Ciprofloxacin resisten terhadap Klebsiella sebesar $80 \%$, Pseudomonas $75 \%$ dan Enterobacter 100\%. Ceftriaxon resisten terhadap Klebsiella sebesar 88,89\% dan terhadap Pseudomonas $100 \% .{ }^{20}$

Resistensi antibakteri dapat terjadi karena berbagai hal, antara lain adanya perubahan pada target, inaktivasi dari antibakteri, berkurangnya permeabilitas dinding sel bakteri, adanya blokade pada jalur masuk antibakteri dan perubahan jalur metabolik bakteri ${ }^{14,21}$. Meningkatnya angka resistensi pada penelitian ini disebabkan karena didominasi oleh bakteri batang Gram negatif yang kemungkinan besar menghasilkan plasmid yang mengkode gen resistensi ${ }^{14}$. Adanya resistensi terhadap bakteri batang Gram negatif sebagai penyebab ISK disebabkan karena bakteri ini menghasilkan enzim terkait plasmid berupa Extended spectrum beta lactamase ( ESBL). ESBL ini dapat menginaktivasi sebagian besar antibiotik golongan beta laktam seperti penisilin, sefalosporin dan monobaktam serta dapat menimbulkan resistensi silang dengan beberapa antibiotik lain 
seperti golongan florokuinolon, aminoglikosida, tetrasiklin dan trimetoprimsulfametoksazol. ${ }^{22}$

\section{KESIMPULAN DAN SARAN}

Sebagian besar subjek yang menggunakan kateter $(61,29 \%)$ menderita ISK terkait kateter yang didominasi oleh Gram negatif (57,89\%). Resistensi tertinggi ditemukan pada cefotaxim, cefriaxon, cefalexin dan tetracyclin (100\%). Resistensi terendah ditemukan pada merofenem dan trimetoprimsulfametoxazol $(73,68 \%)$.

Berdasarkan kesimpulan tersebut diperlukan adanya pengawasan dan kebijakan terhadap penggunaan antibakteri yang rasional untuk mencegah peningkatan resistensi antibakteri. Selain itu juga perlu penelitian lebih lanjut untuk mengetahui penyebab meningkatnya resistensi di RSUD Arifin Achmad Pekanbaru serta identifikasi bakteri batang Gram negatif penghasil ESBL sebagai salah satu penyebab resistensi antibakteri di rumah sakit.

\section{UCAPAN TERIMA KASIH}

Pada kesempatan ini penulis menyampaikan terima kasih kepada: Lembaga Penelitian Universitas Riau yang telah membantu peneliti atas dana penelitian PIP UR 2011, Direktur beserta Staf RSUD Arifin Achmad Pekanbaru yang telah membantu peneliti dalam mendapatkan sampel penelitian serta seluruh pihak yang telah membantu kelancaran penelitian ini.

\section{DAFTAR PUSTAKA}

1. Nguyen HT. Bacterial Infections of Genitourinary Tract. In: Tanagho MA, McAnich JW, editors. Smith's General Urology. $17^{\text {th }}$ ed. New York: McGraw-Hill Companies, Inc. 2008. p.193-218.

2. Bircan Z. Review article urinary tract infection and the pediatricians. Internasional Pediatrics. 2002; 17(3): 143-44.

3. Rusdidjas, Ramayati R. Infeksi saluran kemih. In: Alatas H, Tambunan T, Trihono PP, editor. Nefrologi Anak. Edisi 2. Jakarta: Balai Penerbit FKUI.2004: 142-61.
4. Purnomo BB. Dasar-Dasar Urology. Jakarta: Sagung Seto, 2000: 37-61

5. Tanagho E.A Lange Medical Books. Smith's general urology, sixteenth edition. 2004. New York.

6. Chenowet CE,Saint S. Infection Assosiated with Urinary Catheters. In: Seifert H, Jansen B, Farr $\mathrm{BM}$, editors. Catheter-related Infection. $2^{\text {nd }} \mathrm{ed}$. New York: Marcel Dekker; 2006. p.490-518.

7. Naim R. Penggunaan antibakteri dan mekanisme resistensi bakteri. Medika No.10 Tahun XXIX. Jakarta: Grafiti Medika Pers. 2003: 668-70.

8. Lo E, Nicolle L, Classen D, Arias KM, Podgorny $\mathrm{K}$, Anderson DJ, et al. Strategies to Prevent Catheter-Associated Urinary Tract Infections in Acute Care Hospital. Infect Control Hosp Epidemiol. 2008; 29(Suppl.1): S41-50.

9. Samirah, Darwati, Windarwati, Hardjoeno. Pola dan sensitivitas kuman di penderita infeksi saluran kemih. Indonesia Journal of Clinical Pathology and Medical Laboratory. 2006 : 11013.

10. Widyati Adkk. Kesesuaian kesesuaian pemilihan antibakteria dengan hasil kultur dan uji sensitivitas serta efektivitasnya berdasarkan parameter angka lekosit urin pada pasien infeksi saluran kemih rawat inap di rumah sakit panti rapih yogyakarta (juli - desember 2004); [Diakses 25 mei 2009] http://www.usd.ac.id/06/ publ dosen/far/aris.pdf.

11.Dwiprahasto I. Kebijakan untuk meminimalkan risiko terjadinya resistensi Bakteri di unit perawatan intensif rumah sakit. Bagian Farmakologi \& Toksikologi/Clinical Epidemiology \& Biostatistics Unit Fakultas Kedokteran Ugm, Yogyakarta. Vol.08/No.04/ $2005.177=180$

12.CLSI. Performance Standards for Antimicrobial Susceptibility Testing; Twentieth Informational Supplement. CLSI document M100-S20. Wayne, PA: Clinical and Laboratory Standards Institute; 2011

13.Stamm WE. Infeksi saluran kemih dan pielonefritis. Dalam: Harrison Prinsip-Prinsip Ilmu Penyakit Dalam, Vol. 3. Editor: Jmichael Lazarus, Barry MB; Editor Bahasa Indonesia: 
Akhmad H. Asdie - Ed.13. Jakarta: EGC, 2000: 616-622.

14.Brooks GF, Butel JS, Morse SA. Jawetz, Melnick, \& Adelberg's Mikrobiologi Kedokteran, Edisi 23. Jakarta: EGC, 2008: 25163.

15.Wilson LM;. Gagal ginjal kronik. Dalam: Patofisiologi Konsep Klinis Proses-Proses Penyakit. Jakarta: 2006; EGC: 912-947.

16.Sjahrurachman A, Mirawati T, Ikaningsih, Warsa UC. Etiologi dan resistensi bakteri penyebab infeksi saluran kemih di RSCM dan RS MMC Jakarta 2001-2003, Medika, Vol. XXX. Jakarta: Grafiti Medika Pers, 2004: 557-562.

17. Husada S, Hardjowiyoto S, kuntamam, Widodo JP, Gardjito W. Perbandingan dan penyebaran Escherichia coli dan Klebsiella pneumonia Penghasil Extended Spectrum Beta Laktamase pad isolate Urine Pasien Pria dengan kateter dan tanpa Kateter. 2008; 15 (1); 15-20.
18. Wahjono H. Pidato Pengukuhan Peran Mikrobiologi Klinik pada Penanganan Penyakit Infeksi. Semarang: Universitas Diponegoro. 2007. p. $20-28$

19.Taher MT, Golestanpour. Symptomatic nosocomial urinary tract infection in ICU patients identification o antimicrobial resistance pattern. Iranian Journal of Clinical Infection Disease. 2009; 4(1) : 25-9

20.Endriani R, Andrini F, Alfina D. Pola Resistensi Bakteri Penyebab Infeksi Saluran Kemih (ISK) terhadap Anti bakteri di Pekanbaru. Journal Natur Indonesia. 2009;12(2): 130-35

21.Mims C, Dockrell HM, Goering RV, Roitt I, Wakelin D. Medical Microbiology, Third Edition. England: Mosby UK, 2008: 241-248.

22.Bradford PA, Dean CR. Resistance of Gram negative bacilli to Antimicrobial. In: Fong IW, Drlica K, editors. Antimicrobial Resistance \& Implications for the Twenty-First Century. New York: Springer Science+Bussines Media, LLC. 2008. p. 97-159. 